\title{
Optimasi Kondisi Proses Pengendapan Hidroksida Logam - Logam Berat Kromium Dan Nikelsecara Bertingkat Dalam Limbah Cair Elektroplating
}

\author{
Hayu Sanjaya Radix Kristyaka \\ SMA Negeri 1 Pulau Petak Kapuas, Kalimantan Tengah, Indonesia
}

\begin{abstract}
Abstrak :Penelitian ini bertujuan untuk mengetahui kondisi optimum yang meliputi $\mathrm{pH}$, suhu, waktu, dan kecepatan pengadukan proses pengendapan hidroksida logam-logam berat kromium $(\mathrm{Cr})$ dan nikel $(\mathrm{Ni})$ dalam limbah cair electroplating. Sehingga dapat meminimalkan konsentrasi logam-logam berat kromium dan nikel dalam limbah cair electroplating sebelum dibuang ke lingkungan.Sampel limbah cair dalam gelas beker diaduk menggunakan pengaduk magnetik dengan kecepatan pengadukan konstan sambil ditambahkan larutan amonia $10 \%$ secara berlahan-lahan dengan variasi $\mathrm{pH}: 7 ; 7,5 ; 8 ; 8,5$; 9; 9,5; 10; 10,5; dan 11. Larutan ditambah $\mathrm{pH}$ buffer kemudian disamakan volumenya hingga $200 \mathrm{ml}$, setelah itu didiamkan selama 24 jam kemudian filtrat dan endapan dipisahkan. Filtrat dianalisis kandungan sisa $\mathrm{Cr}$ dan Ni menggunakan spektrofotometri serapan atom (SSA). Untuk mengetahui kondisi optimum lainya dilakukan variasi suhu, waktu serta kecepatan pengadukan proses pengendapan.Hasil penelitian menunjukkan bahwa Kondisi $\mathrm{pH}$ optimum pengendapan logam berat $\mathrm{Cr}$ dicapai pada $\mathrm{pH} 9$ dengan $\%$ pengendapan sebesar 79,013\% sedangkan $\mathrm{Ni}$ pada $\mathrm{pH} 9,5$ dengan besarnya $\mathrm{Ni}$ yang terendapkan sebesar $99,71 \%$. Suhu pengendapan optimum untuk $\mathrm{Cr}$ dan Ni dicapai pada suhu $100{ }^{\circ} \mathrm{C}$ dengan \% pengendapan $\mathrm{Cr}$ sebesar 50,304\% dan $\mathrm{Ni}$ sebesar 97,891\%. Waktu pengendapan optimum untuk $\mathrm{Cr}$ adalah 60 menit dengan jumlah pengendapan sebesar 45,542\% sedangkan kondisi waktu pengendapan optimum Ni selama 40 menit dengan \% pengendapan sebesar 99,633\%. Kecepatan pengadukan proses pengendapan $\mathrm{Cr}$ dan $\mathrm{Ni}$ adalah sebesar $800 \mathrm{rpm}$ dengan jumlah $\mathrm{Cr}$ yang mengendap sebesar 63,493\% sedangkan Ni sebesar $98,531 \%$.
\end{abstract}

\section{Kata kunci: elektroplating, pengendapan, logam-logam berat kromium dan nikel}

\section{Pendahuluan}

Limbah memang menjadi salah satu masalah dalam pembangunan sektor industri di Indonesia. Masalah tersebut menyebabkan kemerosotan dan kerusakan lingkungan hidup. Kerusakan lingkungan antara lain disebabkan oleh limbahyang mengandung bahan berbahaya dan beracun (B3) yang dibuang ke lingkungan. Menurut Kementerian Negara Lingkungan Hidup, diperkirakan beban pencemaran limbah B3 akan meningkat dari200.000 ton pada tahun 1990, menjadi sekitar 1 juta ton pada tahun 2010. Untuk itu, pemerintah telah membuat Peraturan Pemerintah Republik Indonesia Nomor 85 Tahun 1999 tentang pengelolaan limbah bahan berbahaya dan beracun (B3). Pemanfaatan limbah adalah salah satu upaya untuk mengurangi volume, konsentrasi, dan tingkat bahaya yang menyebar di lingkungan. Ada beberapa cara pemanfaatan limbah, antara lain : penggunaan kembali (reuse), daur ulang (recycle), dan perolehan kembali (recovery) (Sahat M. Panggabean, $2000: 131)$. 
Di Indonesia banyak sekali berdiri industri-industri dengan berbagai bidang produksi, salah satu diantaranya adalah industri elektroplating (penyepuhan), yaitu industri pelapisan logam dengan menggunakan ion-ion logam lain yang bertujuan untuk memanipulasi sifat suatu logam tertentu dengan metode elektrolisis. Proses elektroplating banyak dibutuhkan oleh industri penghasil benda-benda logam, diantaranya industri komponen elektronika, peralatan listrik, peralatan permesinan, peralatan dapur, dan sebagainya. Saat ini kebutuhan penggunaan logam-logam berlapis hasil industri elektroplating banyak dibutuhkan karena selain sifat logam-logam tersebut menjadi tahan karat, lebih mengkilap, juga memiliki tampilan yang lebih baik jika dibandingkan dengan logam-logam yang tidak dilapis.

Dalam setiap proses produksi selalu dihasilkan limbah, begitu juga dalam industri elektroplating. Limbah yang dihasilkan dalam industri elektroplating berasal dari air pembilas baik yang digunakan untuk mencuci minyak dan lemak pada logam yang akan dilapis, bilasan setiap tahap pengerjaan logam, maupun bilasan tahap akhir proses elektroplating. Pada bilasan tahap akhir proses elektroplating terkandung beberapa logam-logam alkali, asam-asam kuat, dan logam-logam berat antara lain $\mathrm{Cd}, \mathrm{Cr}, \mathrm{Cu}, \mathrm{Ni}, \mathrm{Pb}$, dan $\mathrm{Zn}$. (Evi. A, Sri. W, Agustini. R., 2004 : 28).

Limbah cair elektroplating berbahaya jika terjadi kontak dengan tubuh manusia, karena dapat menyebabkan iritasi pada kulit, selaput lendir, selaput mata dan saluran pernafasan, selain itu jika tertelan dapat menyebabkan mual, pusingpusing, lemas, bahkan sampai terjadinya kematian. Namun demikian,jika logamlogam berat berbahaya yang ada dalam limbah buangan tersebut dihilangkan terlebih dahulu maka tidak akan mencemari lingkungan.

Pemisahkanlogam-logam berat dalam limbah elektroplating dapat dilakukan dengan cara mengambilnya dari limbah cair tersebut. Metode pemisahan yang dapat digunakan antara lain dengan metode adsorbsi, elektrodialisis, ekstraksi logam, osmosis balik, kromatografi penukar ion, membran cair, pengendapan dan sebagainya.

Pengendapan merupakan salah satu metode pemisahan unsur-unsur logam yang terlarut yang banyak digunakan. Pengendapan dilakukan dengan mengubah ion logam yang akan dipisahkan menjadi suatu fasa baru yaitu dalam bentuk padatan (endapan). Pengendapan ini terjadi karena ion logam tersebut berada dalam bentuk persenyawaan dimana harga hasil kali konsentrasi ion-ionnya melebihi harga hasil kali kelarutan $\left(\mathrm{K}_{\mathrm{sp}}\right)$ senyawa tersebut. Hasil kali kelarutan $\left(\mathrm{K}_{\mathrm{sp}}\right)$ adalah hasil kali konsentrasi ion-ion dalam larutan jenuh pada suhu tertentu setelah masing-masing konsentrasi dipangkatkan dengan koefisiennya menurut persamaan ionisasi senyawanya. Ada beberapa faktor yang mempengaruhi proses pengendapan, yaitu : $\mathrm{pH}$ larutan, suhu pengendapan, konsentrasi pengendap, waktu pengendapan, dan kecepatan pengadukan(Sukarsono dkk., 1966 : 55 ). 
Untuk mendapatkan endapan logam yang terlarut dalam air limbah dapat dilakukan dengan beberapa metode pengendapan yaitu pengendapan sulfat, karbonat, fosfat, bikromat, dan hidroksida. Pengendapan hidroksida merupakan salah satu cara untuk memisahkan atau mengambil ion-ion logam yang terdapat dalam limbah cair dengan cara menambahkan larutan amonium hidroksida $\left(\mathrm{NH}_{4} \mathrm{OH}\right)$, kalsium hidroksida $\left[\mathrm{Ca}(\mathrm{OH})_{2}\right]$, atau natrium hidroksida $(\mathrm{NaOH})$ ke dalam sampel limbah cair yang terdapat ion-ion logam sehingga terbentuk endapan hidroksida logam $\mathrm{M}(\mathrm{OH})_{\mathrm{n}}$. Pengendapan hidroksida dilakukan secara bertingkat dengan melakukan variasi $\mathrm{pH}$ larutan. Pada proses pengendapan dengan larutan hidroksida diperlukan kondisi $\mathrm{pH}$ pengendapan yang baik agar ion-ion logam yang terdapat di dalam filtrat dapat mengendap secara maksimum (konsentrasi tinggi). Selain itu kondisi suhu larutan, waktu pengadukan, serta kecepatan pengadukan juga berpengaruh terhadap proses pengendapan logamlogam berat tersebut.

Berdasarkan uraian tersebut di atas maka penelitian ini bertujuan untuk mengetahui kondisi optimum pada proses pengendapan ion-ion logam yang terlarut dalam limbah elektroplating terutama logam kromium dan nikel yang merupakan logam terbanyak yang ada dalam limbah tersebut.

\section{Metode Penelitian}

Pada penelitian ini subyek penelitian ini adalah logam-logam berat nikel dan kromium dalam limbah cair industri elektroplating, sedangkan obyek penelitian ini adalah optimasi pada proses pengendapan logam logam berat nikel dan kromium sebagai senyawa hidroksidanya. Variabel terikatnya merupakan volume sampel limbah dan konsentrasi reagen $\mathrm{NH}_{3}$, sedangkan variabel bebasnya berupa $\mathrm{pH}$, suhu, waktu, dan kecepatan pengadukan pada proses pengendapan.

\section{Prosedur Penelitian}

1. Pembuatan larutan reagen

a. Larutan $\mathrm{NH}_{3} 10 \%$

Diambil larutan $\mathrm{NH}_{3} 25 \%$ sebanyak $40 \mathrm{ml}$ kemudian diencerkan dalam labu ukur $100 \mathrm{ml}$ dengan cara ditambah aquades hingga volumenya tepat $100 \mathrm{ml}$.

b. Larutan Standar Cr dan Ni

Larutan Cr 1000 ppm sebanyak $100 \mu \mathrm{l}$ diambil kemudian dimasukkan ke dalam gelas ukur kemudian ditambah aquades hingga volumenya $2 \mathrm{ml}$ ( larutan induk). Dari larutan induk diambil masing-masing sebanyak $50 \mu \mathrm{l}$, $100 \mu \mathrm{l}, 150 \mu \mathrm{l}, 200 \mu \mathrm{l}, 250 \mu \mathrm{l}$ kemudian dimasukkan kedalam labu ukur 5 ml, masing-masing ditambah larutan $\mathrm{HNO}_{3}$ 0,1 M sebanyak $500 \mu \mathrm{l}$, dan ditambah aquades hingga volumenya tepat $5 \mathrm{ml}$ sehingga konsentrasinya masing-masing adalah 0,5 ppm, 1 ppm, 1,5 ppm, $2 \mathrm{ppm}$, dan 2,5 ppm. 
Langkah tersebut diulangi untuk pembuatan larutan standar $\mathrm{Ni}$ namun untuk membuat larutan induk menggunakan larutan Ni 100 ppm

2. Penentuan $\mathrm{pH}$ optimum proses pengendapan

a. Sampel limbah sebanyak $100 \mathrm{ml}$ diambil kemudian dimasukkan ke dalam gelas beker $200 \mathrm{ml}$

b. Dilakukan pengadukan dengan pengaduk magnetik dengan kecepatan pengadukan konstan selama 15 menit sambil ditambahkan larutan $\mathrm{NH}_{3}$ $10 \%$ secara berlahan-lahan hingga $\mathrm{pH}$ masing-masing $7 ; 7,5 ; 8 ; 8,5 ; 9$; 9,5;10; 10,5; dan 11 .

c. Masing-masing larutan ditambah larutan $\mathrm{pH}$ buffer yang sesuai dengan $\mathrm{pH}$ larutan hingga pHnya tidak berubah kemudian ditepatkan hingga volume $200 \mathrm{ml}$ kemudian didiamkan selama 24 jam.

d. Endapan dan filtrat dipisahkan dengan cara disaring menggunakan kertas saring.

e. Filtrat hasil penyaringan kemudian dianalisis konsentrasi sisa $\mathrm{Cr}$ dan $\mathrm{Ni}$ menggunakan SSA

3. Penentuan suhu optimum proses pengendapan

a. Sampel limbah sebanyak $100 \mathrm{ml}$ diambil kemudian dimasukkan ke dalam gelas beker $200 \mathrm{ml}$

b. Dilakukan pengadukan dengan pengaduk magnetik dengan kecepatan pengadukan konstan selama 15 menit sambil ditambahkan larutan $\mathrm{NH}_{3}$ $10 \%$ secara berlahan-lahan hingga $\mathrm{pH}$ optimum kemudian masing-masing larutan dipanaskan dengan variasi suhu $25^{\circ} \mathrm{C}, 40^{\circ} \mathrm{C}, 60^{\circ} \mathrm{C}, 80^{\circ} \mathrm{C}$, dan $100^{\circ} \mathrm{C}$

c. Larutan didiamkan selama 24 jam.

d. Filtrat dan endapan dipisahkan dengan cara disaring.

e. Larutan dianalisis konsentrasi Cr menggunakan SSA

f. Langkah a sampai e dilakukan untuk penentuan $\mathrm{Ni}$

4. Penentuan waktu optimum proses pengendapan

a. Sampel limbah sebanyak $100 \mathrm{~mL}$ diambil kemudian dimasukkan ke dalam gelas beker $200 \mathrm{ml}$

b. Dilakukan pengadukan dan pemanasan dengan pengaduk magnetik dengan suhu optimum dan kecepatan konstan sambil ditambahkan larutan $\mathrm{NH}_{3}$ $10 \%$ secara berlahan-lahan hingga $\mathrm{pH}$ optimum dengan variasi waktu pengadukan masing-masing 10, 20, 30, 40, 50, dan 60 menit

c. Filtrat dan endapan dipisahkan dengan cara disaring.

d. Larutan dianalisis konsentrasi Cr menggunakan SSA

e. Langkah a sampai d dilakukan untuk penentuan $\mathrm{Ni}$

5. Penentuan kecepatan pengadukan optimum

a. Sampel limbah sebanyak $100 \mathrm{~mL}$ diambil kemudian dimasukkan ke dalam gelas beker $200 \mathrm{ml}$ 
b. Dilakukan pemanasan dengan suhu dan waktu optimum sambil ditambahkan larutan $\mathrm{NH}_{3} 10 \%$ secara berlahan- lahan hingga $\mathrm{pH}$ optimum sambil dilakukan pengadukan dan dengan variasi kecepatan pengadukan masing-masing : 200, 400, 600, 800, dan $1000 \mathrm{rpm}$

c. Larutan didiamkan selama 24 jam.

d. Filtrat dan endapan dipisahkan dengan cara disaring.

e. Larutan dianalisis konsentrasi Cr menggunakan SSA

f. Langkah a sampai e dilakukan untuk penentuan $\mathrm{Ni}$

\section{Hasil Penelitian Dan Pembahasan}

\section{Optimasi pH Pengendapan}

Data analisis filtrat hasil pengendapan bertingkat pada masing-masing $\mathrm{pH}$ yang berupa konsentrasi dan \% pengendapan kromium dan nikel dapat dilihat pada tabel 1

Tabel 1. Hasil Pengamatan Konsentrasi Kromium dan Nikel dalam Filtrat

Hasil Pengendapan Hidroksida Secara Bertingkat Dengan Variasi pH

\begin{tabular}{|c|c|c|c|c|c|c|}
\hline \multirow{2}{*}{$\mathbf{p H}$} & \multicolumn{3}{|c|}{$\mathbf{C r}$} & \multicolumn{3}{c|}{$\mathbf{N i}$} \\
\cline { 2 - 7 } & $\begin{array}{c}\mathbf{C}_{\text {sisa }} \\
(\mathbf{p p m})\end{array}$ & $\begin{array}{c}\mathbf{C}_{\text {mengendap }} \\
(\mathbf{p p m})\end{array}$ & $\begin{array}{c}\text { \%Pengendapa } \\
\mathbf{n}\end{array}$ & $\begin{array}{c}\mathbf{C}_{\text {sisa }} \\
(\mathbf{p p m})\end{array}$ & $\begin{array}{c}\mathbf{C}_{\text {mengendap }} \\
(\mathbf{p p m})\end{array}$ & $\begin{array}{c}\text { \%Pengendapa } \\
\mathbf{n}\end{array}$ \\
\hline 7 & 5.103 & 0 & 0 & 5.166 & 0 & 0 \\
\hline 7.5 & 3.074 & 2,056 & 39.761 & 5.101 & 0,065 & 1.259 \\
\hline 8 & 2.594 & 2,509 & 49.168 & 0.91 & 4,256 & 82.385 \\
\hline 8.5 & 1.367 & 3,736 & 73.212 & 0.332 & 4,843 & 93.574 \\
\hline 9 & 1.071 & 4,032 & 79.013 & 0.062 & 5,104 & 98.8 \\
\hline 9.5 & 1.462 & 3,641 & 71.351 & 0.017 & 5,149 & 99.671 \\
\hline 10 & 1.078 & 4,025 & 78.876 & 2.714 & 2,452 & 57.918 \\
\hline 10.5 & 1.386 & 3,717 & 72.84 & 4.818 & 0,348 & 6.737 \\
\hline 11 & 2.21 & 2,893 & 56.693 & 4.85 & 0,316 & 6,116 \\
\hline
\end{tabular}

Dari hasil penelitian diketahui bahwa jumlah logam berat kromium awal sebesar 5,103 ppm sedangkan logam berat nikel adalah sebesar 5,166 ppm. Setelah dilakukan tahap penentuan kondisi $\mathrm{pH}$ pengendapan optimum dapat diketahui kondisi $\mathrm{pH}$ optimum untuk mengendapkan logam berat kromium adalah pada $\mathrm{pH} 9$ dengan jumlah $\mathrm{Cr}$ yang mengendap sebanyak 4,032 ppm atau dengan $\%$ pengendapan sebesar 79,013 \%. Endapan kromium(III)hidroksida $\left(\mathrm{Cr}(\mathrm{OH})_{3}\right)$ berwarnahijaukeabu-abuan. Grafik hubungan antara \% pengendapan dengan $\mathrm{pH}$ pengendapan $\mathrm{Cr}$ dapat dilihat pada gambar1 


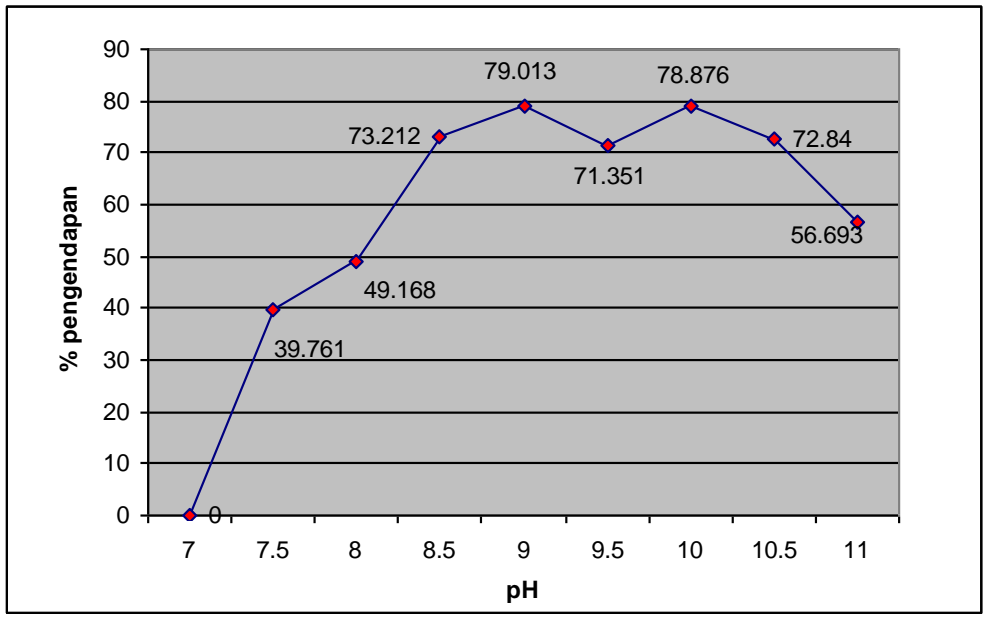

\section{Gambar 1. Grafik Hubungan Antara pH Pengendapan Terhadap \% Pengendapan Kromium}

Nikel mulai mengendap pada $\mathrm{pH}$ 7,5 hingga mencapai nilai pengendapn yang maksimum pada $\mathrm{pH}$ 9,5 dengan jumlah nikel yang mengendap sebanyak 5,149 ppm atau dengan nilai \% pengendapan sebesar 99,671\%. Endapan nikel(II)hidroksida $\mathrm{Ni}(\mathrm{OH})_{2}$ berwarna hijau. Grafik hubungan antara\% pengendapan dengan $\mathrm{pH}$ pengendapan $\mathrm{Ni}$ dapat dilihat pada gambar 2.

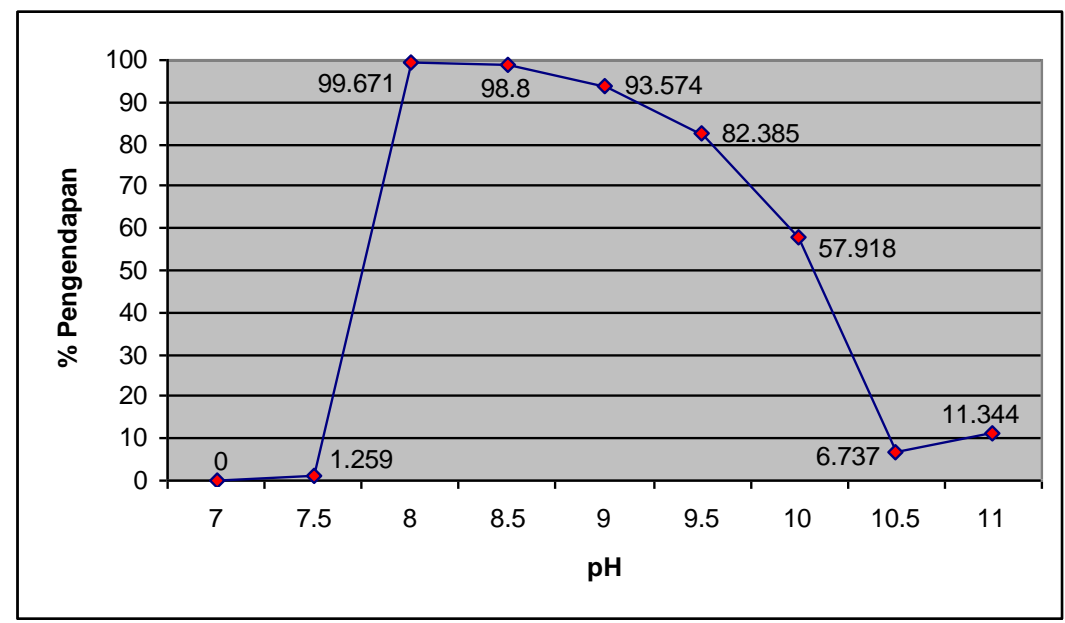

\section{Gambar 2. Grafik Hubungan Antara pH Pengendapan Terhadap \% Pengendapan Nikel}

\section{Optimasi Suhu Pengendapan}

Hasil pengamatan konsentrasi kromium dan nikel dalam filtrat hasil pengendapan hidroksida secara bertingkat dengan variasi suhu dapat dilihat pada tabel 2.

Tabel 2. Hasil Pengamatan Konsentrasi Kromium dan Nikel Dalam Filtrat

\section{Hasil}


Pengendapan Hidroksida Secara Bertingkat Dengan Variasi Suhu

\begin{tabular}{|c|c|c|c|c|c|c|}
\hline \multirow{2}{*}{$\begin{array}{c}\text { Suhu } \\
\left({ }^{\mathbf{0}} \mathbf{C}\right)\end{array}$} & $\begin{array}{c}|c| \\
\mathbf{C}_{\text {sisa }} \\
(\mathbf{p p m})\end{array}$ & $\begin{array}{c}\mathbf{C}_{\text {mengendap }} \\
(\mathbf{p p m})\end{array}$ & \%Pengendapan & $\begin{array}{c}\mathbf{C}_{\text {sisa }} \\
(\mathbf{p p m})\end{array}$ & $\begin{array}{c}\mathbf{C}_{\text {mengendap }} \\
(\mathbf{p p m})\end{array}$ & \%Pengendapan \\
\hline 25 & 3.477 & 1,626 & 31.864 & 0.236 & 4,236 & 95.342 \\
\hline 40 & 3.429 & 1,674 & 32.805 & 0.165 & 5,001 & 96.807 \\
\hline 60 & 3.237 & 1,866 & 36.567 & 0,157 & 5,009 & 96,961 \\
\hline 80 & 3,397 & 1,706 & 33,432 & 0,141 & 5,025 & 97,271 \\
\hline 100 & 2.536 & 2,567 & 50.304 & 0.109 & 5,057 & 97.891 \\
\hline
\end{tabular}

Pada tahap ini, kromium mengendap paling besar pada saat suhu $100^{\circ} \mathrm{C}$ dengan konsentrasi sebesar 2,567 ppm atau dengan \% pengendapan sebesar $50,304 \%$. Grafik hubungan antara suhu pengendapan dengan \% pengendapan $\mathrm{Cr}$ dapat dilihat pada gambar 3 .

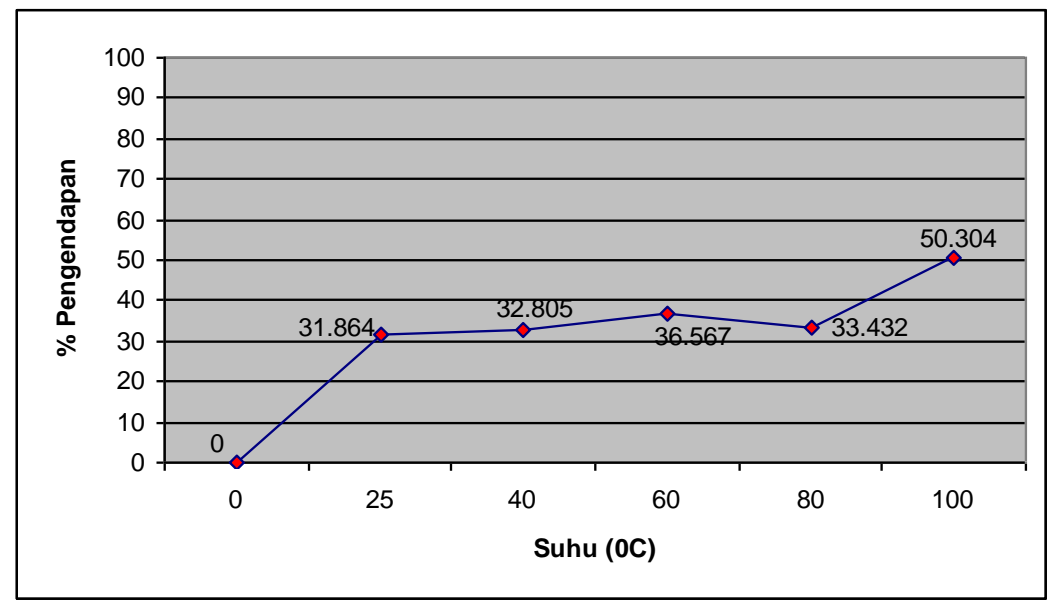

\section{Gambar 3. Grafik Hubungan Antara Suhu Pengendapan Terhadap \% Pengendapan Kromium}

Pada tahap ini nikel juga mengendap paling baik pada suhu $100{ }^{0} \mathrm{C}$ yaitu dengan konsentrasi sebesar 5,057 ppm atau dengan \% pengendapan sebesar 97,981\%.Grafik hubungan antara suhu pengendapan dengan $\%$ pengendapan $\mathrm{Ni}$ dapat dilihat pada gambar 4. 


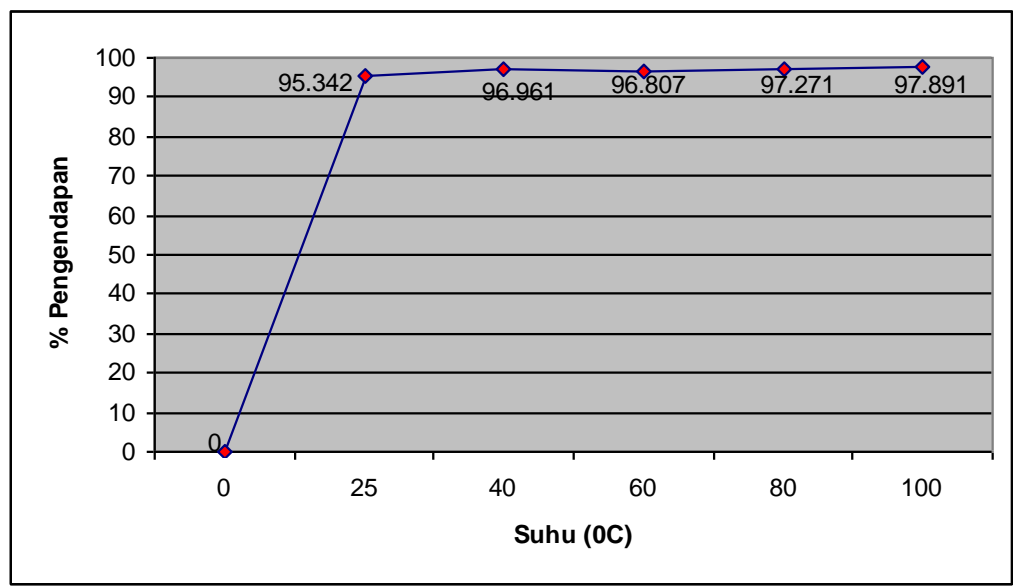

\section{Gambar 4.Grafik Hubungan Antara Suhu Pengendapan Terhadap \% Pengendapan Nikel}

\section{Optimasi Waktu Pengendapan}

Hasil pengamatan konsentrasi kromium dan nikel dalam filtrat hasil pengendapan hidroksida secara bertingkat dengan variasi waktu pengendapan dapat dilihat pada Tabel 3.

\section{Tabel 3. Hasil Pengamatan Konsentrasi Kromium dan Nikel Dalam Filtrat Hasil}

Pengendapan Hidroksida Secara Bertingkat Dengan Variasi Waktu

\begin{tabular}{|c|c|c|c|c|c|c|}
\hline \multirow{2}{*}{$\begin{array}{c}\text { Waktu } \\
(\text { Menit) }\end{array}$} & \multicolumn{3}{|c|}{$\mathbf{C r}$} & \multicolumn{3}{c|}{ Ni } \\
\cline { 2 - 7 } & $\begin{array}{c}\mathbf{C}_{\text {sisa }} \\
\mathbf{p p m})\end{array}$ & $\begin{array}{c}\mathbf{C}_{\text {mengendap }} \\
(\mathbf{p p m})\end{array}$ & \% Pengendapan & $\begin{array}{c}\mathbf{C}_{\text {sisa }} \\
(\mathbf{p p m})\end{array}$ & $\begin{array}{c}\mathbf{C}_{\text {mengendap }} \\
(\mathbf{p p m})\end{array}$ & \% Pengendapan \\
\hline 10 & 3.214 & 1,889 & 37.018 & 0.105 & 5,061 & 97.968 \\
\hline 20 & 3.214 & 1,889 & 37.018 & 0.06 & 5,106 & 98.839 \\
\hline 30 & 2.888 & 2,215 & 43.406 & 0.048 & 5,118 & 99.071 \\
\hline 40 & 2.919 & 2,184 & 42.799 & 0.019 & 5,147 & 99.633 \\
\hline 50 & 2.903 & 2,2 & 43.112 & 0.029 & 5,137 & 99.439 \\
\hline 60 & 2.779 & 2,324 & 45.542 & 0.034 & 5,132 & 99.342 \\
\hline
\end{tabular}

Kromium mengendap paling baik setelah dilakukan pengadukan dan pemanasan selama 60 menit dengan konsentrasi sebesar 2,324 ppm atau sebesar 45,542\% dari konsentrasi awal dalam limbah. \% Grafik hubungan antara waktu pengendapan dengan $\%$ pengendapan $\mathrm{Cr}$ dapat dilihat pada gambar 5. 


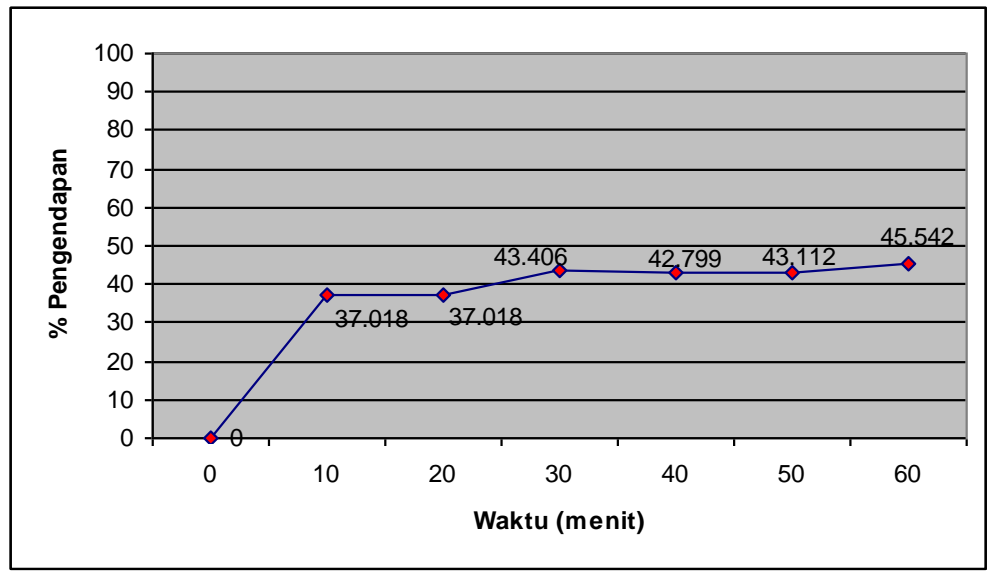

\section{Gambar 5. Grafik Hubungan Antara Waktu Pengendapan Terhadap \% Pengendapan Kromium}

Nikel mengendap paling baik setelah dilakukan proses pengendapan selama 40 menit dengan jumlah $\mathrm{Ni}$ yang mengendap sebanyak 5,147 ppm atau dengan $\%$ pengendapan sebesar 99,633\%. Grafik hubungan antara waktu pengendapan dengan $\%$ pengendapan $\mathrm{Ni}$ dapat dilihat pada gambar 6 .

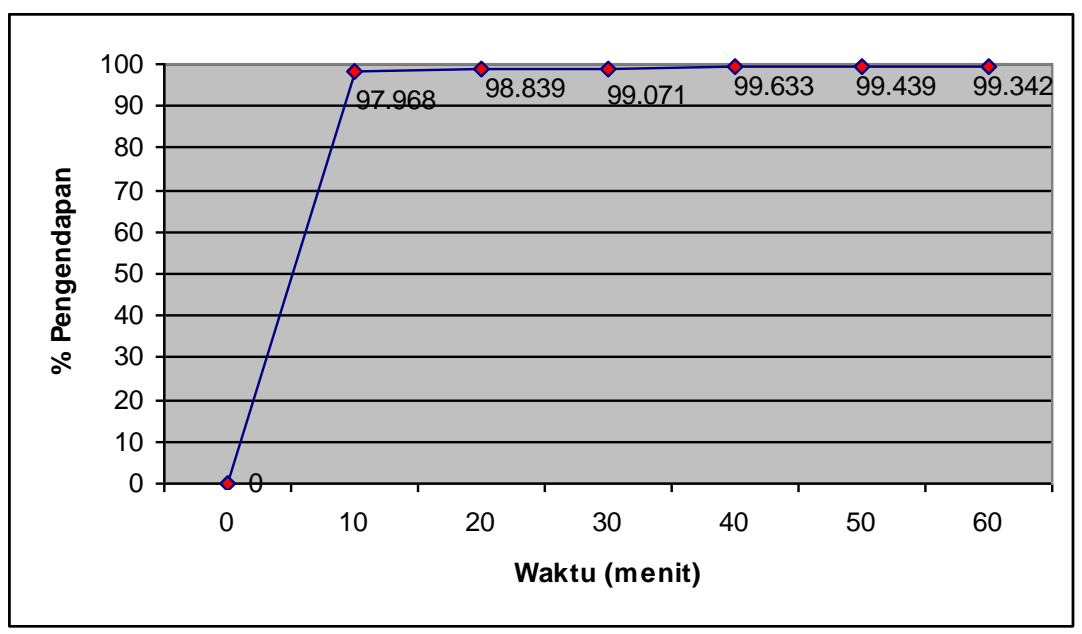

Gambar 6. Grafik Hubungan Antara Waktu Pengendapan Teerhadap \% Pengendapan Nikel

\section{Optimasi Kecepatan Pengadukan}

Data hasil penentuan kecepatan pengadukan optimal proses pengendapan terhadap logam berat kromium dan nikel dapat dilihat pada Tabel 4. 
Tabel 4. Hasil Pengamatan Konsentrasi Kromium dan Nikel dalam Filtrat

\section{Hasil}

Pengendapan Hidroksida Secara Bertingkat dengan Variasi Kecepatan

\section{Pengadukan}

\begin{tabular}{|c|c|c|c|c|c|c|}
\hline \multirow{2}{*}{$\begin{array}{c}\text { Kec. } \\
\text { Pengadukan } \\
(\mathbf{r p m})\end{array}$} & \multicolumn{3}{|c|}{$\mathbf{C r}$} & \multicolumn{3}{c|}{ Ni } \\
\cline { 2 - 7 }$\left(\mathbf{\mathbf { C } _ { \text { sisa } }}\right.$ & $\begin{array}{c}\mathbf{C}_{\text {mengendap }} \\
(\mathbf{p p m})\end{array}$ & \%Pengendapan & $\begin{array}{c}\mathbf{C}_{\text {sisa }} \\
(\mathbf{p p m})\end{array}$ & $\begin{array}{c}\mathbf{C}_{\text {mengendap }} \\
(\mathbf{p p m})\end{array}$ & \%Pengendapan \\
\hline 200 & 2,901 & 2,202 & 43,152 & 0,46 & 4,706 & 90,986 \\
\hline 400 & 2,773 & 2,33 & 45,66 & 0,159 & 5,007 & 96,923 \\
\hline 600 & 2,38 & 2,723 & 53,361 & 0,089 & 5,007 & 98,278 \\
\hline 800 & 1,863 & 3,24 & 63,493 & 0,075 & 5,091 & 98,531 \\
\hline 1000 & 2,091 & 3,012 & 59,025 & 0,145 & 5,021 & 97,194 \\
\hline
\end{tabular}

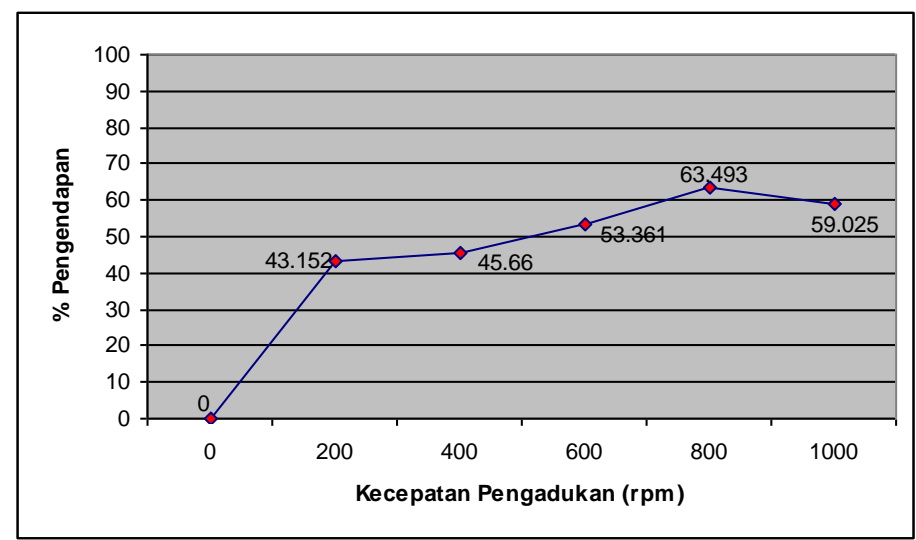

Gambar 7.Grafik Hubungan Antara Kecepatan Pengadukan Terhadap \% Pengendapan Kromium

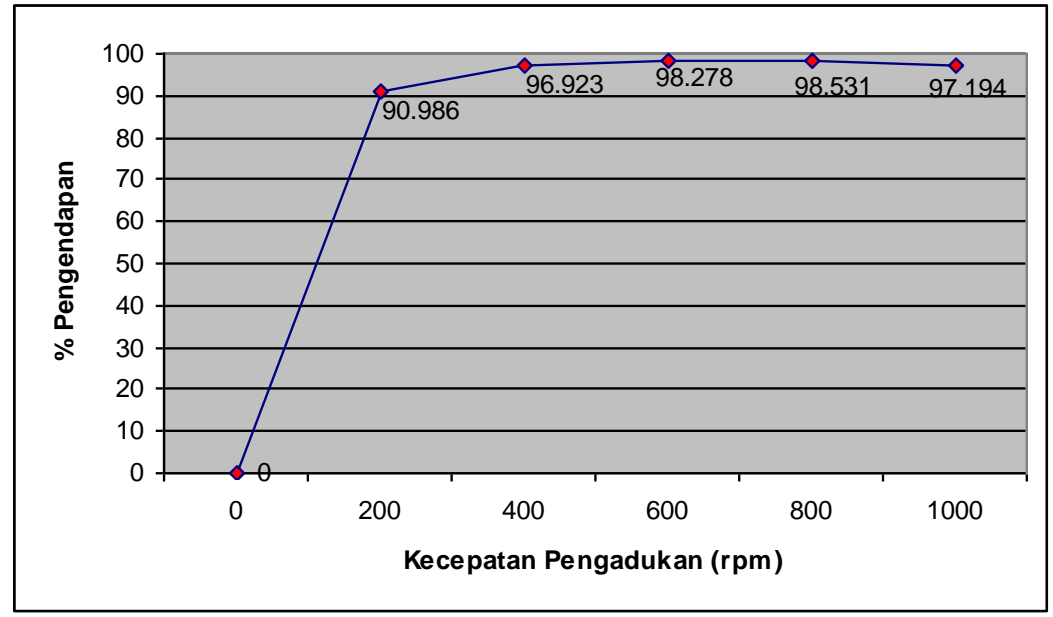

Gambar 8. Grafik Hubungan Antara Kecepatan Pengadukan Terhadap \% Pengendapan Nikel

Pada proses ini $\mathrm{Cr}$ mengendap paling baik pada saat dilakukan pengadukan dengan kecepatan sebesar 800 rpm dengan konsentrasi sebesar 3,24 
ppm atau dengan \% pengendapan sebesar 63,493\%. Grafik hubungan antara kecepatan pengadukan dengan \% pengendapan $\mathrm{Cr}$ dapat dilihat pada gambar 7 .

Nikel mengendap paling baik setelah dilakukan proses pengendapan dengan kecepatan pengadukan sebesar 800 rpm dengan konsentrasi sebanyak 5,091 ppm atau dengan \% pengendapan sebesar 98,531\%. Grafik hubungan antara kecepatan pengadukan dengan \% pengendapan $\mathrm{Cr}$ dapat dilihat pada gambar 7 .

\section{B. Pembahasan}

\section{Optimasi pH Pengendapan}

Pengendapan hidroksida merupakan cara pemisahan logam-logam berat dengan cara menambahkan ion hidroksi sehingga membentuk endapan hidroksida logam dimana harga hasil kali konsentrasi ion-ionnya melebihi harga hasil kali kelarutan $\left(\mathrm{K}_{\mathrm{sp}}\right)$ senyawa tersebut.Pada proses pengendapan secara hidroksida konsentrasi ion hidroksil memegang peranan yang sangat penting. Hal ini disebabkan karena hasil kali konsentrasi ion hidrogen dan hidroksil adalah konstan $\left(\mathrm{Kw}=10^{-14}\right)$, dengan demikian pembentukan endapan logam hidroksida tergantung pada $\mathrm{pH}$ larutan. Untuk memisahkan logam-logam berat dapat dilakukan pengendapan secara bertingkat dengan memvariasikan perlakuan $\mathrm{pH}$. Pengendapan hidroksida secara bertingkat terhadap limbah cair dengan kandungan logam-logam berat dapat dilakukan dengan cara $100 \mathrm{ml}$ limbah cair dalam gelas beker diaduk menggunakan pengaduk magnetik dengan kecepatan pengadukan konstan sambil ditambahkan larutan amonia 10\% secara berlahanlahan dengan variasi $\mathrm{pH}: 7 ; 7,5 ; 8 ; 8,5 ; 9 ; 9,5 ; 10 ; 10,5$; dan 11 . Kemudian larutan ditambah larutan buffer kemudian disamakan volumenya hingga $200 \mathrm{ml}$, setelah itu didiamkan selama 24 jam agar semua endapan yang terbentuk mengendap di permukaan larutan untuk mempermudah penyaringan. Setelah itu filtrat dan endapan disaring menggunakan kertas saring sehingga endapan dan filtrat terpisahkan. Filtrat dianalisis kandungan sisa kromium dan nikel menggunakan spektrofotometri serapan atom (SSA).

Penggunaan larutan amonia $10 \%$ bertujuan untuk memperoleh hasil endapan yang baik serta dapat lebih mudah mengatur $\mathrm{pH}$ larutan jika dibandingkan dengan penggunaan ion hidroksi atau reagen lain dengan konsentrasi yang lebih pekat dan variasi $\mathrm{pH}$ disini bertujuan untuk mengetahui $\mathrm{pH}$ optimum untuk mengendapkan logam-logam berat $\mathrm{Cr}$ dan $\mathrm{Ni}$. Pada $\mathrm{pH} 7$ endapan belum terbentuk, endapan baru mulai terbentuk pada $\mathrm{pH}$ 7,5 hingga mencapai pengendapan yang maksimum untuk logam berat $\mathrm{Cr}$ pada $\mathrm{pH} 9$ dengan terbentuknya endapan kromium(III)hidroksida $\left[\mathrm{Cr}(\mathrm{OH})_{3}\right]$ yang berwarnahijaukeabu-abuan melalui reaksi sebagai berikut :

$$
\mathrm{Cr}^{3+}+3 \mathrm{NH}_{3}+\mathrm{H}_{2} \mathrm{O} \longrightarrow \mathrm{Cr}(\mathrm{OH})_{3}(\mathrm{~s})+3 \mathrm{NH}_{4}^{+}
$$

Pada kondisi diatas $\mathrm{pH} 9, \mathrm{Cr}$ cenderung melarut kembali karena sifat amfoterik yang dimilikinya dengan membentuk senyawa kompleks heksaaminokromat(III) melalui reaksi sebagai berikut :

$$
\left.\mathrm{Cr}(\mathrm{OH})_{3}(\mathrm{~s})+6 \mathrm{NH}_{3} \longrightarrow \mathrm{Cr}\left(\mathrm{NH}_{3}\right)_{6}\right]^{3+}+3 \mathrm{OH}^{-}
$$


Hal ini dapat tejadi karena kelebihan reagen pengendap $\mathrm{NH}_{3}$ yang menyebabkan endapan yang telah terbentuk melarut kembali dengan membentuk senyawa kompleks heksaaminokromat(III). Sedangkan pada saat kondisi pH optimum terjadi reaksi kesetimbangan :

$$
\mathrm{Cr}(\mathrm{OH})_{3} \rightleftharpoons \mathrm{Cr}^{3+}+3 \mathrm{OH}^{-}
$$

Dengan persamaan tetapan kesetimbangan :

$$
\mathrm{K}_{\mathrm{sp}} \mathrm{Cr}(\mathrm{OH})_{3}=\left[\mathrm{Cr}^{3+}\right] \times\left[\mathrm{OH}^{-}\right]^{3}
$$

Pada 9 Endapan terbentuk sudah maksimal karena nilai $\mathrm{K}_{\mathrm{sp}}$ dari senyawa $\mathrm{Cr}(\mathrm{OH})_{3}$ sebesar $7 \times 10^{-31}$ dapat dilampaui oleh nilai dari hasil kali ion-ion penyusunnya $\left(\left[\mathrm{Cr}^{3+}\right] \times\left[\mathrm{OH}^{-}\right]^{3}\right)$ yaitu sebesar $8,064 \times 10^{-19}$ dengan kata lain, pada kondisi tersebut larutan telah lewat jenuh sehingga $\mathrm{Cr}$ mengendap maksimal. Pada kondisi dibawah pH 9 memang telah mulai terbentuk endapan namun kurang maksimal karena konsentrasi ion hidroksil lebih sedikit dibandingkan pada $\mathrm{pH} 9$ yang mempengaruhi perhitungan hasil kali ion-ion penyusunnya. Namun Jika penambahan ion hidroksil dilanjutkan yang menyebabkan kenaikan $\mathrm{pH}$ justru dapat menyebabkan sebagian endapan melarut kembali sebagai akibat terbentuknya senyawa kompleks.

Nikel mulai mengendap pada $\mathrm{pH}$ 7,5 hingga mencapai nilai pengendapn maksimum pada $\mathrm{pH}$ 9,5 dengan jumlah nikel yang mengendap sebanyak 5,149 ppm atau dengan nilai \% pengendapan sebesar 99,671\% dengan terbentuknya endapan nikel(II)hidroksida $\mathrm{Ni}(\mathrm{OH})_{2}$ berwarna hijauberdasarkan reaksi :

$$
\mathrm{Ni}^{2+}+2 \mathrm{NH}_{3}+2 \mathrm{H}_{2} \mathrm{O} \longrightarrow \mathrm{Ni}(\mathrm{OH})_{2}(\mathrm{~s})+\mathrm{NH}_{4}^{+}
$$

Pengendapan dapat terjadi karena nilai hasil kali ion-ion penyusun senyawa tersebut $\left(\left[\mathrm{Ni}^{2+}\right] \times\left[\mathrm{OH}^{-}\right]^{2}\right)$ adalah sebesar $3,257 \times 10^{-18}$ telah dapat melampauinilai $\mathrm{K}_{\mathrm{sp}}$ senyawa $\mathrm{Ni}(\mathrm{OH})_{2}$ tersebut yaitu sebesar $8,7 \times 10^{-19}$. Pada $\mathrm{pH}$ diatas 9,5 nikel cenderung melarut kembali karena kelebihan zat pengendap yang menyebabkan terbentuknya senyawa kompleks $\left[\mathrm{Ni}\left(\mathrm{NH}_{3}\right)_{6}\right]^{2+}$ berdasarkan reaksi :

$$
\left.\mathrm{Ni}(\mathrm{OH})_{2}(\mathrm{~s})+6 \mathrm{NH}_{3} \quad \mathrm{Ni}\left(\mathrm{NH}_{3}\right)_{6}\right]^{2+}+2 \mathrm{OH}^{-}
$$

Perbedaan kondisi $\mathrm{pH}$ optimum antara $\mathrm{Cr}$ dan $\mathrm{Ni}$ disebabkan karena perbedaan $\mathrm{K}_{\mathrm{sp}}$ antara $\mathrm{Cr}(\mathrm{OH})_{3}$ dan $\mathrm{Ni}(\mathrm{OH})_{2}$, meskipunkedunya sama-sama mulai mengendap pada $\mathrm{pH}$ yang sama namun $\mathrm{Cr}(\mathrm{OH})_{3}$ dapat lebih dahulu mencapai kondisi kelewat jenuhannya, kondisi dimana hasil kali kelarutan ion-ion penyusunnya mampu melampaui nilai $\mathrm{K}_{\mathrm{sp}}$ nya dibandingkan dengan senyawa $\mathrm{Ni}(\mathrm{OH})_{2}$. Hubungan antara $\mathrm{K}_{\mathrm{sp}}$ dengan $\mathrm{pH}$ adalah dengan perubahan $\mathrm{pH}$ maka konsentrasi ion hidroksil juga berubah sehingga mempengaruhi nilai hasil kali kelarutan atau hasil kali ion-ion penyusunnya. Dalam sampel limbah konsentrasi $\mathrm{Cr}$ dan $\mathrm{Ni}$ adalah tetap, namun dengan variasi $\mathrm{pH}$ maka besarnya hasil kali kelarutan dapat berubah sebanding dengan perubahan $\mathrm{pH}$ atau dengan konsentrasi ion hidroksil.

\section{Optimasi Suhu Pengendapan}

Pada penentuan suhu optimum proses pengendapan logam-logam berat $\mathrm{Cr}$ dan Ni dilakukan dengan cara: $100 \mathrm{ml}$ sampel limbah cair dalam gelas beker 
diaduk dan dipanaskan menggunakan pengaduk magnetik yang dilengkapi pemanas dengan variasi suhu sebesar $25,40,60,80$, dan $100{ }^{0} \mathrm{C}$ sambil ditambahkan larutan amonia 10\% hingga $\mathrm{pH}$ optimum yaitu $\mathrm{pH} 9$ untuk $\mathrm{Cr}$ dan pH 9,5 untuk Ni. Setelah terbentuk endapan kemudian didiamkan selama 24 jam setelah itu filtrat dan endapan dipisahkan dengan cara disaring menggunakan kertas saring kemudian filtrat hasil penyaringan dianalisis kandungan sisa logamlogam $\mathrm{Cr}$ dan Ni menggunakan SSA. Tujuan dilakukannya variasi suhu adalah untuk mengetahui kondisi suhu optimum proses pengendapan logam-logam berat Cr dan Ni.

Dari hasil pengamatan dapat dilihat bahwa dengan kenaikan suhu menunjukkan kecenderungan peningkatan jumlah yang mengendap terhadap logam berat kromium maupun nikel. Pengendapan $\mathrm{Cr}$ dan $\mathrm{Ni}$ paling baik dilakukan pada saat kondisi suhu $100{ }^{0} \mathrm{C}$ dengan besarnya konsentrasi pengendapan $\mathrm{Cr}$ sebesar 2,567 ppm atau dengan nilai \% pengendapan sebesar $50,304 \%$ sedangkan $\mathrm{Ni}$ sebesar 5,057 ppm atau dengan nilai \% pengendapan sebesar 97,891\%.

Pengaruh perubahan suhu terhadap proses pengendapan adalah dengan bertambahnya suhu reaksi maka kelarutan akan meningkat, hal ini disebabkan karena dengan menaikan suhu berarti menambah energi sehingga gerakan partikel semakin cepat dan semakin mudah reaktan mencapai ion logam yang ada sehingga reaksi yang berlangsung lebih sempurna. Pada tahap awal pembentukan kristal endapan terjadi pembentukan inti-inti endapan dengan cepat karena energi yang cukup besar yang disebabkan oleh tingginya suhu larutan. Inti-inti ini makin lama makin tumbuh, pada saat inti-inti tersebut tumbuh terbentuk lagi inti-inti baru, karena pertumbuhan inti-inti lama lebih cepat maka kebanyakan ion ditarik oleh inti lama untuk pertumbuhannya sehingga semakin sedikit ion yang tersedia untuk pertumbuhan inti baru sehingga inti tetap sedikit dan ion-ion yang berlebih hanya menumbuhkan inti yang sedikit itu menjadi kristal yang butirannya lebih besar. Semakin banyak endapan dengan bentuk kristal kasar lebih memudahkan dalam proses penyaringan.

\section{Optimasi Waktu Pengendapan}

Pada tahap optimasi waktu pengendapan ini dilakukan dengan cara $100 \mathrm{ml}$ sampel limbah cair dalam gelas beker diaduk dan dipanaskan menggunakan pengaduk magnetik yang dilengkapi pemanas dengan suhu optimum $100{ }^{\circ} \mathrm{C}$ dan variasi kecepatan pengadukan konstan sambil ditambahkan larutan amonia 10\% secara berlahan-lahan hingga $\mathrm{pH}$ optimum yaitu $\mathrm{pH} 9$ untuk $\mathrm{Cr}$ dan $\mathrm{pH}$ 9,5 untuk Ni dengan variasi waktu pengadukan masing-masing selama 10, 20, 30, 45, 50, dan 60 menit. Setelah terbentuk endapan kemudian filtrat dan endapan dipisahkan dengan cara disaring menggunakan kertas saring kemudian filtrat hasil penyaringan dianalisis kandungan sisa logam-logam $\mathrm{Cr}$ dan $\mathrm{Ni}$ menggunakan SSA 
Dalam setiap reaksi pengendapan selalu diperlukan waktu untuk melakukan kontak antara unsur yang diendapkan dengan reagen pengendapnya sehingga pada saat tertentu dapat bereaksi sempurna. Semakin lama waktu pengendapan akan semakin banyak jumlah endapan yang diperoleh karena semakin banyaknya waktu kontak antara zat pengendap dengan ion logam pada larutan. Pada proses pengendapan $\mathrm{Cr}$ diperoleh hasil pengendapan paling baik setelah dilakukan proses pengadukan selama 60 menit dengan jumlah $\mathrm{Cr}$ yang mengendap sebesar 2,324 ppm atau dengan nilai \% pengendapan sebesar 45,542 $\%$. Dari data yang diperoleh menunjukkan semakin lama waktu pengendapan maka semakin besar pula jumlah Cr yang mengendap, hal ini disebabkan karena semakin lama waktu pengadukan maka semakin banyak kontak antara reagen pengendap dengan logam berat $\mathrm{Cr}$ sehingga reaksi dapat berlangsung dengan sempurna. Sedangkan untuk penentuan waktu pengendapan optimum $\mathrm{Ni}$ menunjukkan waktu optimal proses pengendapan Ni adalah selama 40 menit dengan konsentrasi $\mathrm{Ni}$ yang mengendap sebanyak 5,147 ppm atau dengan \% pengendapan sebesar $99.633 \%$. Dari kurva hubungan antara konsentrasi sisa $\mathrm{Ni}$ vs waktu pengendapan dapat dilihat semakin banyak waktu yang digunakan semakin berkurang konsentrasi sisa dalam filtrat atau semakin banyak Ni yang mengendap hingga mencapai titik maksimum pada saat 40 menit. Penambahan waktu pengendapan justru berpengaruh terhadap berkurangnya konsentrasi $\mathrm{Ni}$ yang mengendap, hal ini disebabkan karena pada tahap pertumbuhan kristal endapan dengan semakin lama waktu pengadukan maka bentuk endapan ukuranya justru menjadi lebih kecil dan halus bahkan dapat membentuk sistem koloid sehingga endapan menjadi sulit untuk disaring dalam proses penyaringan.

\section{Optimasi Kecepatan Pengadukan}

Dalam proses pengendapan, kecepatan pengadukan sangat berpengaruh dalam proses reaksi antara ion logam $\mathrm{Cr}$ dan $\mathrm{Ni}$ dengan reagen pengendap $\mathrm{NH}_{3}$. Penentuan kecepatan pengadukan optimum proses pengendapan dapat dilakukan dengan cara $100 \mathrm{ml}$ limbah cair dipanaskan dan diaduk menggunakan pengaduk magnetik dengan suhu optimum $\left(80{ }^{0} \mathrm{C}\right)$ serta dilakukan pengadukan dengan variasi kecepatan pengadukan masing-masing sebesar 200, 400, 600, 800, dan $1000 \mathrm{rpm}$ sambil ditambahkan reagen pengendap amonia secara berlahan-lahan hingga $\mathrm{pH}$ optimum yaitu $\mathrm{pH} 9$ untuk pengendapan $\mathrm{Cr}$ dan $\mathrm{pH}$ 9,5 untuk pengendapan Ni. Setelah terjadi endapan kemudian endapan dan filtrat dipisahkan dengan cara disaring menggunakan kertas saring kemudian filtratnya dianalisis kandungan sisa $\mathrm{Cr}$ dan Ni menggunakan SSA. Tujuan dilakukannya variasi kecepatan pengadukan ini adalah untuk mengetahui berapakah kecepatan pengadukan yang paling baik dalam proses pengendapan logam-logam berat kromium dan nikel dalam limbah cair.

Kecepatan pengadukan sangat berpengaruh terhadap kecepatan dan hasil reaksi karena semakin cepat pengadukan maka akan semakin besar jumlah tumbukan antar molekul sehingga makin banyak zat pengendap yang bereaksi 
dengan ion logam sehingga reaksi dapat berlangsung lebih cepat serta lebih merata sehingga didapatkan endapan dengan bentuk yang baik. Baik Pada proses pengendapan $\mathrm{Cr}$ maupun $\mathrm{Ni}$, endapan paling banyak diperoleh pada saat kecepatan pengadukan sebesar $800 \mathrm{rpm}$. Dari grafik yang diperoleh dapat dilihat bahwa semakin cepat proses pengadukan menunjukkan kecenderungan semakin banyak pula endapan yang terbentuk hingga mencapai titik maksimum kecepatan pengadukan yaitu pada saat kecepatannya mencapai 800 rpm. Pada kecepatan diatas $800 \mathrm{rpm}$ menunjukkan penurunan besarnya konsentrasi endapan, hal ini dikarenakan flok-flok endapan yang telah terbentuk hancur dan menjadi terlarut kembali karena tumbukan antar partikel yang terlalu keras yang disebabkan oleh kecepatan dan tekanan yang terlalu besar.

\section{Kesimpulan}

Hasil penelitian tentang optimasi kondisi proses pengendapan hidroksida logam-logam berat kromium dan nikel dalam limbah cair electroplating secara bertingkat diperoleh hasil sebagai berikut :

1. $\mathrm{pH}$ optimum pengendapan logam berat kromium yaitu pada kondisi $\mathrm{pH} 9$ Sedangkan untuk pengendapan logam berat nikel pada $\mathrm{pH}$ 9,5

2. Suhu optimum proses pengendapan logam berat kromium yaitu pada suhu 100 ${ }^{0} \mathrm{C}$ Sedangkan untuk pengendapan logam berat nikel pada suhu $100{ }^{\circ} \mathrm{C}$

3. Waktu optimum proses pengendapan logam berat kromium yaitu selama 60 menit. Sedangkan untuk pengendapan logam berat nikel selama 40 menit

4. Kecepatan pengadukan optimum proses pengendapan logam berat kromium yaitu sebesar 800 rpm. Sedangkan untuk pengendapan logam berat nikel sebesar $800 \mathrm{rpm}$.

\section{Daftar Rujukan}

R. A. Day. Jr, A. L. Underwood (1986). Analisis Kimia Kuantitatif, edisi kelima. Jakarta : Erlangga

Lide, D.R. (2002-2003). Handbook of Chemistry and Physic. New York : Boca Rator London.

Kristian H Sugiyarto. (2004). Kimia Anorganik III. Yogyakarta : FMIPA Universitas Negeri Yogyakarta.

Siti Sulastri M, Si. dan Susila Kristianingrum M, Si. (2003). Kimia Analisis Instrumen. Yogyakarta: FMIPA Universitas Negeri Yogyakarta.

Heryando Palar. (1994). Pencemaran \& toksikologi logam berat. Jakarta : PT.Rineka Cipta

Harrizal Rivai. (1995). Asas Pemeriksaan Kimia. Jakarta : Universitas Indonesia

S. M. Khopkar. (2002). Konsep Dasar Kimia Analit. Jakarta : Universitas Indonesia

Segal, B. G. (1980). Chemistri Eypirement and Theory $2^{\text {nd }}$ Eedition. New York : Boca Rator London. 
Evi. A, Sri. W, Agustini. R. (2004). Perolehan Kembali Cu dari LimbahElektroplating Menggunakan Reaktor Unggun Terfluidasi. Vol 6. Jawa

Barat : Universitas Pasundan.

Sahat. M. Panggabean. (2000). Pengambilan kembali logam berat seng dari air limbah industri. Yogyakarta : BATAN

Ahmad Shoiful. (2005). Adsorbsi Logam Berat Krom dalam Limbah Cair Elektroplating Menggunakan Zeolit. Yogyakarta : BATAN

Dani. G. S, Saeful. H, Deni Juanda. A. S, Efrizon. U. (1993) Pengaruh Suhu Pemanasan dan Tingkat Perolan Terhadap Kecepatan Pertumbuhan Butir dan Pengintian Zirkaloy-4. Yogyakarta : BATAN

Indra Suryawan dan Kasilani. N. (1997). Kajian reaksi campuran torium dan uranil nitrat dengan pereaksi ammonium hidroksida. Yogyakarta : BATAN

Lailatul Hasanah (2007). Optimasi Proses Pembuatan Oksida Logam Tanah Jarang dari Pasir Senotim dan Analisis Produk dengan Spektrometer Pendar Sinar-X. Yogyakarta : FMIPA Universitas Negeri Yogyakarta.

Roekmijati. W. S, Praswasti. P. D. K, dan Yulianti. (2006) Presipitasi bertahap logam berat limbah cair industry pelapisan logam menggunakan larutan soda kaustik. Jakarta : Fakultas Teknik Universitas Indonesia

Sukarman Amijoyo. (1981). Pengaruh pH Final dan Waktu Kontak pada SifatSifat Ammonium Diuranat. Yogyakarta : BATAN

Svehla, Ph.D. , D.Sc. , F. R. I. C (1985). Buku Teks Analisis Anorganik Kualitatif Makro Dan Semi Makro. Edisi ke Lima Jakarta : PT. Kalman

Media Pustaka

W. Harjadi. (1990). Ilmu Kimia analitik Dasar. Jakarta : PT Gramedia 